\title{
Impact of Professional Development Training Curriculum on Practicing Algebra Teachers
}

\author{
Mariyam Shahuneeza Naseer \\ Islamic University of Maldives, Violet Magu, Malé, Republic of Maldives \\ e-mail: shahuneeza@teachers.org
}

\begin{abstract}
Abstrak
Aljabar merupakan dasar penalaran matematika dan pemecahan masalah yang kompleks yang mengharuskan guru matematika memiliki kemampuan yang memadai untuk membelajarkan siswanya. Namun demikian, guru-guru matematika di Maladewa masih memiliki kekurangan baik dalam hal konten aljabar maupun pengetahuan pedagogis yang terkait dengan aljabar. Penelitian ini bertujuan untuk menyajikan sebuah kurikulum pengembangan profesi guru matematika yang dirancang untuk memecahkan masalah performa guru pada materi aljabar tersebut. Penelitian ini melibatkan lima subjek yang merupakan guru-guru matematika kelas 6 sekolah dasar. Model pengembangan profesi guru menurut Desimone digunakan sebagai pedoman pembahasan pada penelitian ini. Pada akhirnya, program pengembangan profesi guru matematika ini dapat meningkatkan pengetahuan konten dan pedagogis subjek pada materi aljabar yang berikutnya mampu meningkatkan prestasi belajar siswa.
\end{abstract}

Kata Kunci: aljabar, pengembangan profesi, guru matematika, model Desimone

\begin{abstract}
Algebra is a foundation for mathematics reasoning and complex problem-solving which then requires mathematics teachers to have adequate proficiency to make their students understand about it. The mathematics teachers in the Maldives, however, lacked both the algebraic content and pedagogical knowledge. This study aims to present a mathematics professional development training curriculum designed to address the issue of the teachers' performance in algebra. There were five participants involved in this study who teach mathematics in the sixth grade of elementary school. Desimone's conceptual model for professional development was used to guide the mathematics professional development for algebra teachers discussed in this paper. This mathematics professional development was found to improve the algebraic content and pedagogical knowledge of the participants, which in turn improved student performance.
\end{abstract}

Keywords: algebra, professional development, mathematics teachers, Desimone's model

How to Cite: Naseer, M.S. (2018). Impact of Professional Development Training Curriculum on Practicing Algebra Teachers. International Journal on Emerging Mathematics Education, 2(2), 187202. http://dx.doi.org/10.12928/ijeme.v2i2.10055

\section{INTRODUCTION}

Professional development curriculum serves to improve instruction in order to improve student learning. According to the NCTM (2010), research on professional development advocated that mathematics professional development (MPD) was effective when it promoted mathematics teachers' growth in four major areas. The areas highlighted in the NCTM (2010) include (1) building teachers' mathematical knowledge and their capacity to use it in practice, (2) building teachers' capacity to notice, analyze, and respond to students' thinking, (3) building teachers' productive habits of mind, and (4) building collegial relationships and structures that support continued learning. 


\section{Background}

A baseline survey conducted by the United Nations Children's Fund and the National Institute of Education to assess student performance during 2012 and 2013 in the Maldives showed that algebra is the lowest performing area of mathematics, with only 27.1\% students obtaining the correct answers to algebra questions (UNICEF \& NIE, 2014). Algebra is a fundamental topic which is first introduced in the sixth grade in the Maldives curriculum. Therefore, teachers who introduce algebra are responsible to facilitate their students constructing their algebraic understanding (Strand \& Mills, 2014). A mixedmethods concurrent multicase study design research was conducted to examine the algebraic content and pedagogical knowledge of sixth grade mathematics teachers to identify their strengths and weaknesses in these areas (Naseer, 2016).

The results of the study revealed that the sixth grade mathematics teachers lacked of algebraic content and pedagogical knowledge, but interestingly, they were confident to believe that they had sufficient knowledge to teach algebra at the sixth grade based on the textbook. According to Naseer (2016) algebraic content and pedagogical knowledge weaknesses identified through observations of algebra lessons, analysis of algebra lesson plans and lesson notes, interviews, and administration of DTAMS included lack of conceptual understanding of algebraic concepts; participants' were deficient with regards to reasoning and problem-solving skills; participants lacked pedagogical knowledge required to teach algebraic ideas and concepts; participants followed the textbook word for word; participants were unable to detect incorrect explanations given in the textbooks; participants ignored the incorrect answers given by the students; participants taught for the exams instead of understanding; participants never attended a MPD; and participants identified factorizing (factoring) and removing brackets (expansion of algebraic expressions) as areas where they needed help. Moreover, the results were also discussed in various academic forum with the targeted stakeholders and lead to the idea to design a model of professional development (MPD).

In the Maldives, it is mandatory for public school teachers to undergo 15 hours of professional development each academic year. It is noteworthy that all five participants of algebraic content and pedagogical knowledge of sixth grade mathematics teachers completed 15 hours of professional development each year since 2009 (Naseer, 2016). However, none of them attended an MPD. Hence, the participants reported that professional development did not contribute towards the enhancement of mathematics content or pedagogical knowledge (Naseer, 2016). Due to limited resources and trained teachers, schools release teachers on three full days to complete 15 hours of mandatory professional development each academic year, two days during the first semester and one day during the second semester as per the calendar set by the Ministry of Education. On each day teachers complete five hours of professional development. In order to make this MPD realistic and as practical as possible, the MPD is designed for three full days accounting for a total of 15 hours, which will be completed within a year.

Professional development was chosen to address the issues identified in the study of algebraic content and pedagogical knowledge of sixth-grade mathematics teachers. Desimone (2009) highlighted the fact that numerous education reforms count on teacher learning and improved instruction to enhance student achievement. Education reform is, in fact, equal to teacher professional development (Sykes, 1996). The main reason for choosing professional development was that research has indicated the positive impact of professional development on teaching quality and student achievement (Cohen \& Hill, 2001; Garet et al., 1999; Hill \& Ball, 2004; Lane et al., 2015; Polly, 2015; Taton, 2015). Specifically, MPD has been identified as a critical component of mathematics education

IJEME, Vol. 2, No. 2, September 2018, 187-202 
reform as there is evidence that MPD enhanced instruction which in turn improved student achievement (Higgins \& Parsons, 2009; Lane et al., 2015; Loucks-Horsley et al., 2010; Polly, 2015).

An MPD was seen as the most appropriate to address the lack of algebraic content and pedagogical knowledge for three main reasons. First, the teachers heavily depend on the textbook and follow the textbook word-for-word even if the concept presented in the textbook is incorrect. Second, the results showed that teachers lacked algebraic content and pedagogical knowledge. Third, recommendations received from the academics were to conduct MPD as educating the teachers would bring a lasting change and improve classroom instruction. Hence, the purpose of this study was to prepare a mathematics teacher professional development curriculum to build on the strengths and improve the weaknesses identified in order to enhance algebra instruction.

\section{Research Questions}

Specifically, this study seeks to answer the following questions: (1) What is the impact of MPD on the teachers' algebraic content and pedagogical knowledge as measured by DTAMS post-test?, and (2) What is the impact of MPD sessions on the students' performance in algebra as measured by test scores?

\section{Literature Review}

The literature includes a wide variety for what might be included as professional development. However, it all boils down to any activity that prepares teachers to improve the performance of students through teacher learning and enhanced instruction.

Effective professional development is defined as providing needed support to continuously improve the performance of educators that enable them to successfully reach all students by addressing inequities in teaching quality and educational resources across classrooms through collaborative professional learning which would positively contribute towards the continuous improvement of student achievement (Mizell et al., 2011). Professional development is found effective when it addresses the specific needs of the participants which also becomes the reflection of the needs of their students (Barrett et al., 2015; Polly, 2015; Taton 2015). Participants of professional development are practicing adults (Barrett et al., 2015; Lehiste, 2015). Adults only learn what interests them and what they feel is relevant, unlike the academic system in which students are forced to study subjects which educators think useful. Therefore, when planning professional development, it is important to be aware of adult learning theories which in turn help in integrating multiple learning styles that cater the needs of the participants.

Participants or the audience of professional development should be consulted to identify the areas they need professional help with. In adult education, it is the "students" who decide the curriculum (Knowles et al., 2005). The facilitator should be aware that, just like children, adults also learn in different ways and at different paces. Including scientific stream and artistic stream in professional development will help cater to the needs of different learners. Unlike children, adults learn more from the experiences. An important aspect of adult learning is learner being able to examine previous experiences based on the new knowledge acquired, which is the basis of cognitive theory (Jackson, 2009). Therefore, in order to implement professional development, it is important to do the follow-up. It is important to check if the teachers are reflecting on their previous teaching and learning experiences based on the new knowledge and also whether they are integrating the acquired knowledge in the classrooms. 
Goldsmith et al. (2014) reviewed 106 refereed articles written on professional learning of practicing mathematics teachers and suggested that effective professional development should cover the following components.

1. Changes in teacher beliefs which included their beliefs about mathematics and its teaching, students and other beliefs related to teaching;

2. Changes in teachers' instructional practices which included changes in mathematics content covered in teachers' lessons, changes in the way discussions are carried out, and promoting students' intellectual autonomy;

3. Teachers' collaboration which included lesson study groups, video clubs, arranging courses and workshops, online or in person discussions, and one-onone coaching;

4. Teachers attention to students' thinking which included how to look at students' work and explore the students' mathematical thinking and understanding of concepts;

5. Enhance teachers' mathematics content; and

6. Focus on curriculum and instructional tasks.

Desimone (2009) listed the following steps as the steps a core theory of action for professional development should include:

1. Teachers experience effective professional development;

2. The professional development increases teachers' knowledge and skills and/or changes their attitudes and beliefs;

3. Teachers use their new knowledge and skills, attitudes, and beliefs to improve the content of their instruction or their approach to pedagogy, or both;

4. The instructional changes foster increased student learning.

The steps are reflected in Desimone's (2009) conceptual model for professional development as shown in Figure 1.

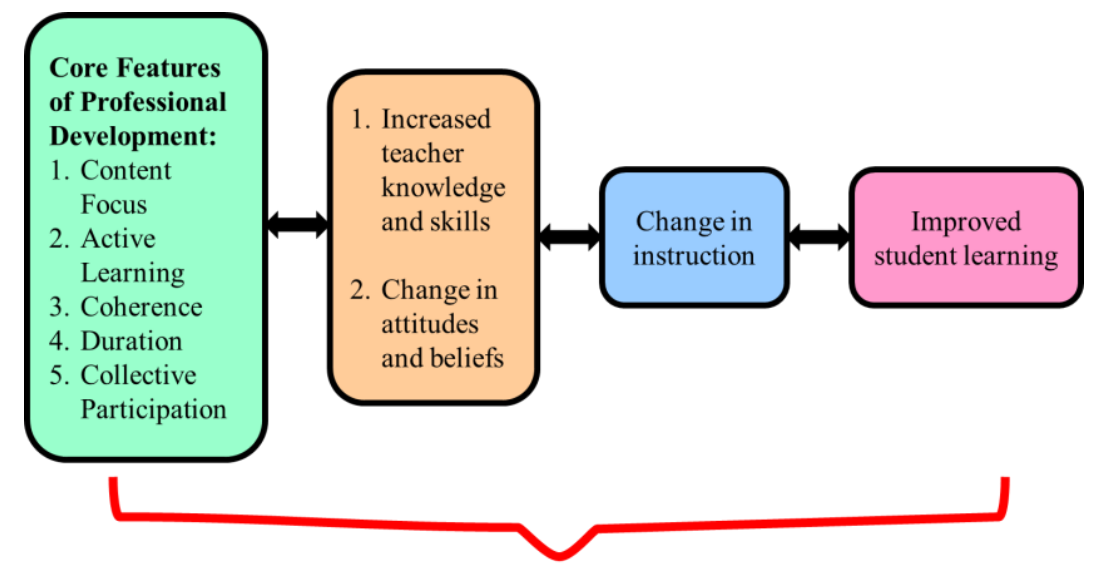

Context such as teacher and student characteristics, curriculum, school leadership, policy environment

Figure 1. Conceptual model for professional development

It is noteworthy that this conceptual model also highlighted the components identified by other researchers as critical components of effective professional development. In addition, Desimone's model included an additional feature measuring the influence of professional development. 
The content focus of teacher professional development is the most influential feature. Evidence from past literature showed professional development that focused on subject matter content increased student achievement (Barrett et al., 2015; Desimone, 2009; Polly, 2015; Taton, 2015). This clearly indicates the importance of focusing on the subject matter knowledge when planning professional development for in-service teachers.

Active learning is also a core feature of effective professional development rather than teachers being passive recipients of knowledge (Desimone, 2009). Desimone (2009) stated that active learning could take different forms. For example, observing expert teachers teach, or letting experts observe one's own teaching and getting interactive feedback, analyzing students' work, and leading and taking part in discussions are considered as active learning (Borko, 2004; Desimone, 2009). Research also showed that continuous professional development enhanced student achievement rather than one-time professional development. In fact, professional development that spread over a semester or a year and which lasted 20 or more hours showed significant gains in student achievement (Desimone, 2009; Polly, 2015). Collective participation creates room for collaboration. This creates opportunities for teachers to take charge of their own learning and improve areas they need help more through collaboration (Desimone, 2009; Knowlton et al., 2015).

Professional development and student learning are very much related. Professional development enriches teacher knowledge and skills that in turn improve classroom teaching which results in raising student achievement (Lomos et al., 2011). Mizell et al., (2011) also confirmed that collaboration and professional learning among the educators increased student achievement. Goldsmith et al. (2014) reported that professional development contributed to enhancing the instructional practices. For example, teachers who took part in professional development started recognizing different ways of solving problems and emphasized students' understanding rather than their ability to answer questions. Furthermore, it was reported that MPD changed teachers' beliefs about mathematics teaching and their students, their instructional practices, the content of mathematics lessons, and most importantly, the way discussions were carried out, promoting students' intellectual autonomy.

\section{RESEARCH METHOD}

The research design employed to evaluate professional development will be a mixed methods practical action research project as the professional development was planned to address an educational issue identified locally within the classrooms (Creswell, 2012). The short-term objective of the evaluation is to find out the impact of MPD on the algebraic content and pedagogical knowledge of sixth-grade mathematics teachers working in the public schools of the Maldives. Further to this, the long-term objective of this MPD is to find out the impact of professional development on the students' performance in algebra as measured by test scores.

According to Killion \& Roy (2009) professional development evaluations must focus on four major aspects of the work: team efficiency, teaching effectiveness, individual members' contributions, and members' effect on practice and student learning. Therefore, to check whether the short-term objective of the MPD was attained, MPD will be closely monitored during the sessions, at the end of each session, and at the end of the MPD using formative evaluation, and summative evaluation methods. Formative evaluations focus on the efficiency, its completion of planned actions, and the outcomes of those actions whereas summative evaluations focus on 
whether the goal of improving teaching quality and student learning was achieved (Killion \& Roy, 2009).

\section{Formative Evaluation and Justification}

A formative evaluation assesses how well the participants perform, their actions and the short-term outcomes they produce (Killion \& Roy, 2009). In evaluating professional development, actions of participants are often noted in formative evaluations rather than the results (Killion \& Roy, 2009). Therefore, the MPD has been designed in a way that formative evaluation takes place during each and every session.

According to Killion (2008), a logic model is useful in the formative evaluations of professional development. A logic model consists of five components, namely, inputs/resources, actions, initial outcomes, intermediate outcomes, and results. The logic model of evaluation is in line with Desimone's Conceptual Model for Professional Development shown in Figure 1. Tables 1, 2, and 3 show the formative evaluation for the MPD sessions.

Table 1. Formative Evaluation for MPD Day 1

\begin{tabular}{lllll}
\hline \multicolumn{1}{c}{ Inputs/ } & \multicolumn{1}{c}{ Actions } & Initial outcomes & $\begin{array}{c}\text { Intermediate } \\
\text { outcomes }\end{array}$ & \multicolumn{1}{c}{ Results } \\
\hline Support from & - Prepare & - Teachers & Students & $-30 \%$ increase in \\
facilitator to & activities & develop & develop & teachers' algebraic \\
increase & - Prepare & conceptual & conceptual & content and \\
algebraic & questions & understanding & understanding & pedagogical \\
content and & - Identify & - Teachers use & and practice & knowledge \\
pedagogical & appropriate & the activities & applying ideas & $-20 \%$ increase in \\
knowledge, & resources & and the & in solving & students' \\
and & & questions in & complex & assessment scores \\
questioning & their & problems & within a year \\
skills & classrooms & \\
Planned Actions & Intended results & & \\
\hline
\end{tabular}

Table 2. Formative Evaluation for MPD Day 2

\begin{tabular}{|c|c|c|c|c|}
\hline Inputs/resources & Actions & Initial outcomes & $\begin{array}{l}\text { Intermediate } \\
\text { outcomes }\end{array}$ & Results \\
\hline $\begin{array}{l}\text { - Teachers bring } \\
\text { students work } \\
\text { samples } \\
\text { - The facilitator } \\
\text { helps teachers } \\
\text { in categorizing } \\
\text { and analyzing } \\
\text { students' work } \\
\text { samples }\end{array}$ & $\begin{array}{l}\text { - Teachers } \\
\text { analyze } \\
\text { students' work } \\
\text { samples } \\
\text { - Teachers } \\
\text { prepare lesson } \\
\text { plans to } \\
\text { address the } \\
\text { issues } \\
\text { identified }\end{array}$ & $\begin{array}{l}\text { - Teachers use } \\
\text { the lesson } \\
\text { plans in their } \\
\text { lessons } \\
\text { - Students } \\
\text { complete } \\
\text { activities } \\
\text { designed for } \\
\text { them based on } \\
\text { the analysis of } \\
\text { their work } \\
\text { Intended results }\end{array}$ & $\begin{array}{l}\text { Teachers } \\
\text { analyze data } \\
\text { from } \\
\text { assessments to } \\
\text { determine who } \\
\text { needs help most } \\
\text { and what type of } \\
\text { help they need }\end{array}$ & $\begin{array}{l}\text { - } 50 \% \text { increase } \\
\text { in teachers' } \\
\text { algebraic } \\
\text { content and } \\
\text { pedagogical } \\
\text { knowledge } \\
\text { - } 30 \% \text { increase } \\
\text { in students' } \\
\text { assessment } \\
\text { scores within a } \\
\text { year }\end{array}$ \\
\hline
\end{tabular}


Table 3. Formative Evaluation for MPD Day 3

\begin{tabular}{|c|c|c|c|c|}
\hline Inputs/resources & Actions & Initial outcomes & $\begin{array}{l}\text { Intermediate } \\
\text { outcomes }\end{array}$ & Results \\
\hline $\begin{array}{l}\text { - Facilitator } \\
\text { explains } \\
\text { actions } \\
\text { research and } \\
\text { lesson study } \\
\text { - The facilitator } \\
\text { helps teachers } \\
\text { in creating } \\
\text { their own } \\
\text { professional } \\
\text { development } \\
\text { plan } \\
\text { Planned Actions }\end{array}$ & $\begin{array}{l}\text { - Teachers } \\
\text { identify the } \\
\text { areas they } \\
\text { could improve } \\
\text { further } \\
\text { - Teachers } \\
\text { prepare an } \\
\text { action } \\
\text { research plan } \\
\text { and a lesson } \\
\text { study plan }\end{array}$ & $\begin{array}{l}\text { - Teachers } \\
\text { implement } \\
\text { lesson study as } \\
\text { collaborative } \\
\text { professional } \\
\text { development } \\
\text { - Teachers } \\
\text { revise the } \\
\text { lesson plans } \\
\text { and activities } \\
\text { and implement } \\
\text { them again } \\
\text { Intended results }\end{array}$ & $\begin{array}{l}\text { - Teachers } \\
\text { increase their } \\
\text { algebraic } \\
\text { content and } \\
\text { pedagogical } \\
\text { knowledge } \\
\text { - Teachers are } \\
\text { flexible in } \\
\text { catering the } \\
\text { diverse needs } \\
\text { of students in a } \\
\text { classroom }\end{array}$ & $\begin{array}{l}\text { - 75\% increase } \\
\text { in teachers' } \\
\text { algebraic } \\
\text { content and } \\
\text { pedagogical } \\
\text { knowledge } \\
\text { - 40\% increase } \\
\text { in students' } \\
\text { assessment } \\
\text { scores within a } \\
\text { year }\end{array}$ \\
\hline
\end{tabular}

\section{Summative Evaluation and Justification}

A summative evaluation helps to determine whether the goals of professional development have been achieved (Killion \& Roy, 2009). Summative evaluations occur at the end of a planned action. According to Killion and Roy (2009), a useful form of summative evaluations includes completion of pre- and post-tests upon completion of the planned actions. Therefore, the short-term summative evaluation carried out by administration of DTAMS Post-test to determine the change in teachers' algebraic content and pedagogical knowledge right after the completion of 15 hours of MPD.

The long-term summative evaluation takes place one year after the completion of MPD, that is after the teachers implement their action research plan and/or lesson study (Knowlton et al., 2015; Mansour et al., 2014). At this stage two forms of summative evaluations took place. They were: (1) Performance of students will be measured at the end of the year using their end-of-year exam scores; and (2) DTAMS post-test administered to the participants to measure their algebraic content and pedagogical knowledge.

\section{Sampling}

The sampling strategy used in this study was homogeneous purposive sampling. In homogenous sampling, the researcher purposefully selects individuals based on common characteristics (Creswell, 2012). Participants of this study were those five participants who continued until the end of the Naseer (2016) study. They were practicing sixth-grade mathematics teachers.

\section{Data Collection}

Data were collected through DTAMS, interviews, and students' results of algebra component. DTAMS was administered after successful completion of the MPD, which was followed by a face-to-face interview with each participant. In addition, the participants were requested to share the de-identified student mark sheets before and after the MPD to check whether there was any significant difference in student performance. 


\section{Limitations of the Study}

Using students' end of year exam scores and DTAMS post-test to measure the impact of MPD as the exam results might not be exclusively influenced by the MPD. Hence, this is considered one of the limitations of this study. However, literature showed that often student achievement scores and/or pre- and post-test scores of participants are used to measure the effectiveness of professional development (Krawec \& Montague, 2014; Lane et al., 2015). Another limitation of this is that due to the small sample size the evaluation data cannot be generalized outside the participant pool.

\section{RESULTS AND DISCUSSION}

MPD took place on a day in January, April and August 2017. The days were selected keeping in mind to help in-service teachers advance their algebraic content and pedagogical knowledge before the teaching starts. Table 4 shows the timetable used for the professional development sessions. Specific hour-by-hour detail of this training can be provided upon contacting the author.

Table 4. Mathematics Professional Development Timetable

\begin{tabular}{|c|c|c|}
\hline Sessions and Date & 08.30 hours to 11.30 hours & 12.30 hours to 14.30 hours \\
\hline $\begin{array}{l}\text { Mathematics Professional } \\
\text { Development Day } 1 \\
\text { January } 2017\end{array}$ & $\begin{array}{l}\text { - DTAMS pre-test } \\
\text { - Introduction to algebra } \\
\text { - Expansion } \\
\text { - Factoring } \\
\text { - Posing problems }\end{array}$ & $\begin{array}{l}\text { - Textbook and resource } \\
\text { analysis } \\
\text { - Identifying and locating } \\
\text { resources } \\
\text { - Preparation of algebra } \\
\text { lessons }\end{array}$ \\
\hline $\begin{array}{l}\text { Mathematics Professional } \\
\text { Development Day } 2 \\
\text { April } 2017\end{array}$ & $\begin{array}{l}\text { - Analysis of students work } \\
\text { - Identifying errors and } \\
\text { misconceptions } \\
\text { - Categorizing errors and } \\
\text { misconceptions }\end{array}$ & $\begin{array}{l}\text { - Identifying teaching } \\
\text { strategies to remedy the } \\
\text { errors and misconceptions } \\
\text { - Identifying teaching } \\
\text { strategies to prevent the } \\
\text { formation of errors and } \\
\text { misconceptions } \\
\text { - Planning of lessons that } \\
\text { would prevent the } \\
\text { formation of errors and } \\
\text { misconceptions }\end{array}$ \\
\hline $\begin{array}{l}\text { Mathematics Professional } \\
\text { Development Day } 3 \\
\text { August } 2017\end{array}$ & $\begin{array}{l}\text { - Action Research } \\
\text { - Lesson Study }\end{array}$ & $\begin{array}{l}\text { - The individual professional } \\
\text { development plan } \\
\text { - DTAMS post-test }\end{array}$ \\
\hline
\end{tabular}

The goals of this MPD to address the problem identified were:

1. Advance algebraic content and pedagogical knowledge of the teachers through the development of their conceptual understanding, critical thinking, and problemsolving ability.

2. Expand the capacity of the teachers to detect errors and misconceptions students have in algebra through students' responses and answer scripts and identify ways to remedy and prevent the formation of these errors and misconceptions.

3. Promote collegial relationships and structures that support continuous MPD. 
MPD curriculum is designed in a way that each full day of professional development addresses one of the goals identified in the above section. Specific learning outcomes of this MPD are as follows. Upon successful completion of the Professional Development Day 1, the participants would be able to:

1. Develop a comprehensive conceptual understanding of basic to advanced algebraic concepts required to teach algebra in sixth grade.

2. Apply the knowledge gained from this module in solving problems and forming problems that promote critical thinking and analytical abilities among sixth-grade mathematics students.

3. Understand how algebraic concepts relate to everyday life and explain algebraic concepts using developmentally-appropriate strategies to students of varying abilities and levels.

4. Critically analyze textbooks and other resources to identify inaccurate definitions and explanations.

Upon successful completion of the Professional Development Day 2, the participants would be able to:

1. Identify the common errors students make and the misconceptions they have by analyzing students' answers.

2. Categorize the common errors students make and the misconceptions they have.

3. Develop strategies to remedy the common errors students make and the misconceptions they have.

4. Prepare and deliver lessons that would prevent making errors and the formation of misconceptions.

Upon successful completion of the Professional Development Day 3, the participants would be able to:

1. Identify various strategies that could be used to enhance one's own professional learning.

2. Effectively plan professional learning.

3. Collaborate to research, plan and design effective teaching strategies and programs.

4. Self-evaluate the impact of the MPD curriculum on one's own algebraic content and pedagogical knowledge using Diagnostic Teacher Assessments in Mathematics and Science - Middle Mathematics Teacher Assessments (DTAMS) post-test.

\section{Choice of Content of the MPD and Justification}

The goal of the MPD Day 1 is to advance algebraic content and pedagogical knowledge of the teachers through developing their conceptual understanding, critical thinking, and problem-solving ability. Therefore, the program for the MPD Day 1 includes activities that focus on improving the participants' algebraic content and pedagogical knowledge.

The participants of this study, who were the participants of the study presented in Naseer (2016), emphasized procedural knowledge and low-level computational skills through rote-learning and repeated practice, instead of developing mathematical discourse among students through contextualized problem-solving and by making explicit connections among concepts (Naseer, 2016). Van Garderen (2008) attributed teachers' lack of conceptual understanding and problem-solving skills to shortcomings 
in classroom instruction. Krawec \& Montague (2014) linked shortcomings in classroom instruction with lack of conceptual understanding and application skills in middle school mathematics students. To address the issue of lack of conceptual understanding and problem-solving skills in middle school mathematics students, Krawec \& Montague (2014) conducted MPD that focused on developing conceptual understanding and problem-solving skills of middle school mathematics teachers. The results showed that professional development that focused on conceptual understanding and problem-solving skills improved the conceptual understanding and problem-solving skills of their students (Krawec \& Montague, 2014). Hence, the MPD Day 1 is focused on advancing the participants' algebraic content and pedagogical knowledge, their conceptual understanding and problem-solving skills. In addition, it has also included collaboratively planning algebra lessons as one of the activities.

The MPD Day 2 activities focused on providing teachers with the practical application of the knowledge gained on the first day of MPD. Specifically, the goal of the second day is to expand the capacity of the teachers to detect errors and misconceptions of algebra through students' responses and answer scripts and identify ways to remedy and prevent the formation of these errors and misconceptions. The activities of the second day are designed in a very practical way. Teachers are required to bring the incorrect answers of their students and analyze those for possible errors and misconceptions. In addition, they would be required to identify ways of remedying the errors and misconceptions and prevent the formation of such errors and misconception in the future. Effective MPD should not only focus on increasing teachers' mathematical content and pedagogical knowledge but also it is essential to include understanding how students think about and learn mathematics (Krawec \& Montague, 2014; Sowder, 2007). Thus, the MPD Day 2 is focused on understanding how students think and learn mathematics through analysis of students' incorrect answers. To make these MPD sessions as effective and as connected to teachers' classroom experiences, teachers' own student's incorrect answers are used.

The goal of MPD Day 3 is to promote collegial relationships and structures that support continuous MPD. This session is dedicated to exposing the teachers to various strategies that can be used for one's own professional learning in order to empower the teacher to take charge of their own professional growth. Teachers will be guided on how to effectively plan professional learning and also how to effectively collaborate professional learning despite their location and the constraints that arise due to the geographical nature of the islands. Moreover, DTAMS post-test will be administered during this session to assess teachers' algebraic content and pedagogical knowledge strengths and weaknesses. The results will be compared with the results of DTAMS pre-test that was administered earlier during the data collection stage of this study.

Collaborations serve to expose teachers to new pedagogy and learning strategies for students. Knowlton et al. (2015) testified that participants reported collegial relationships and collaborations contributed to increasing their knowledge as well as gain a better perspective on the expectations for their students. Burrows (2015) reported that practices of an effective professional development included clear communications, hands-on activities, reflections and discussions, and intentional collaboration and partnership building. Additionally, the inclusion of hands-on activities encouraged collaboration (Burrows, 2015). Hence, the integration of all these practices in the activities planned for MPD Day 3.

This MPD is seen as a solution to the problems identified in Naseer (2016) as this is designed in a way that addresses each and every problem identified in the

IJEME, Vol. 2, No. 2, September 2018, 187-202 
aforementioned study. Moreover, it was expected that upon successful completion of this MPD teachers will be equipped with the ability to take charge of their own professional growth and professional learning.

\section{The Impact of MPD towards the Teachers' Performance}

Results showed that the aim to reinforce instructional strategies and questioning techniques used by the teachers were proved to be a success. Participants reported that they have actually learned a lot from the MPD. One participant stated that the participant felt MPD contributed to the enhancement of algebra instruction "in fact, more than who teacher training combined" while another participant suggested that "this should be included in the teacher training curriculum too". In addition, participants reported that student achievement was significantly improved in algebra.

To specifically answer the first research question, analysis of DTAMS post-test showed that teachers had improved their performance with regard to algebraic content knowledge and pedagogical knowledge required to teach algebra. Algebraic content knowledge and pedagogical knowledge is highly essential as they affected a teacher's ability to teach algebra (Strand \& Mills, 2014). The main reason why DTAMS post-test was used was to avoid the response bias which could arise if the evaluation depended solely on self-reporting (Ebert-May et al., 2011; Knowlton et al., 2015). Figure 2 summarizes the DTAMS pre- and post-test results.

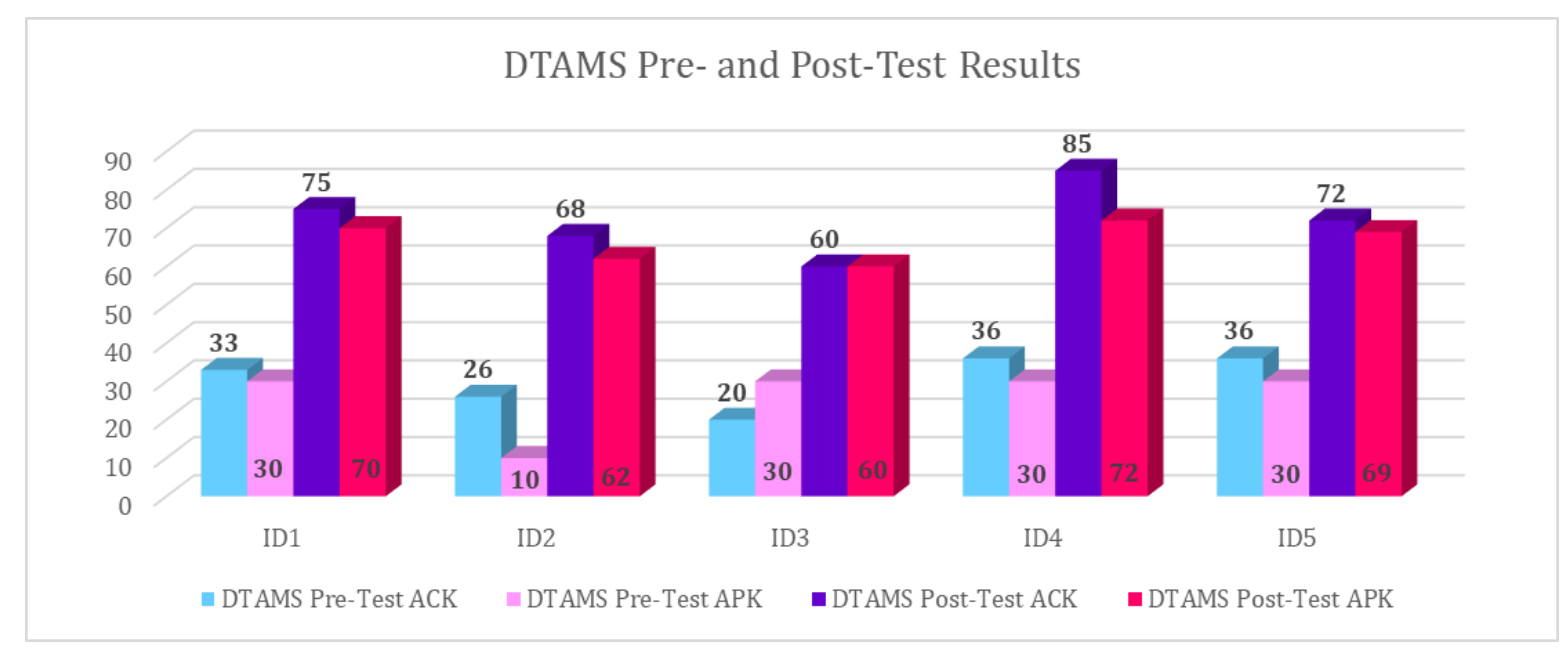

Figure 2. DTAMS pre- and post-test results.

\section{The Impact of MPD towards the Students' Performance}

To specifically answer the second research question, a paired-samples t-test was carried out and the results are presented in Table 5.

Table 5. Results of Paired-Samples t-Test

\begin{tabular}{llllll}
\hline Group & Mean Difference & $n$ & Std. Deviation & $t$-value & $p$-value \\
\hline G1 & 9 & 25 & 6.364 & 7.07 & 0.00 \\
G2 & 7 & 34 & 4.950 & 8.25 & 0.00 \\
G3 & 4 & 30 & 2.828 & 7.75 & 0.00 \\
G4 & 8 & 27 & 5.657 & 7.35 & 0.00 \\
G5 & 13 & 28 & 9.192 & 7.48 & 0.00 \\
\hline
\end{tabular}


As it can be seen from the results in Table 5, the results show that there is a statistically significant improvement in student performance before and after the participants took part in MPD. Research indicated that teacher professional development which focused teacher needs in specific subject areas contributed positively towards the development of students' creativity, their problem-solving skills, and their analytical abilities (Barrett et al., 2015; Baxter et al., 2014; Krawec \& Montague, 2014).

\section{How Theory Relates to Content of the MPD}

The MPD Day 1 includes activities that focus on advancing the algebraic content and pedagogical knowledge of the teachers. The main reason for this is that the related literature showed that the most influential feature of the professional development is the focus on enhancing the content knowledge of the teachers (Polly, 2015; Taton, 2015). Content knowledge of the teachers has been linked to improved instruction and enhanced student achievement (Ball et al., 2008; Desimone, 2009; NCTM, 2010; Polly, 2015; Taton, 2015). The unique feature of this session is that the algebraic content will be covered through varieties of activities incorporating effective pedagogies that could be used to deliver the content. In short, this session would not only enhance the algebraic content knowledge, but also the pedagogical knowledge along with critical thinking, and problem-solving strategies.

The activities planned for MPD Day 2 include providing the teachers opportunity to apply what they have learned and actively engage in identifying workable solutions to problems they have identified through the task assigned by the end of the MPD Day 1. Professional development is effective when the participants see the need for learning and its practical applications (Barrett et al., 2015; Desimone, 2009, Killion \& Roy, 2009; Knowles et al., 2005; Lehiste, 2015). A major task planned for this session is to bring students' work samples and identify the errors and misconceptions from those work samples. In addition, teachers are required to categorize these errors and misconceptions and identify potential causes for these. This practical session that requires the active engagement of teachers would enhance their ability to recognize problems and identify ways to remedy and prevent the formation of these errors and misconceptions.

The MPD Day 3 is planned in a way that lays the foundation for collegial relationships and hence the focus is on identifying ways that promote continuous professional development (Knowlton et al., 2015; Desimone, 2009; Killion \& Roy, 2009). In this session how to conduct research, particularly, action research and also how to conduct a lesson study will also be looked at to give them a firm grounding to plan and begin their own professional learning. Most importantly, teachers will come up with a plan for their own professional learning and identify and form groups to work collaboratively to enrich their algebra knowledge and teaching skills.

To sum up, research has indicated that professional development has the potential to influence the content and pedagogical knowledge, instructional strategies, and consequently student achievement. However, researchers also have noted that professional development research projects face the challenge of establishing validity in researching the relationship between professional development and students' achievement. It is essential to acknowledge the fact that the improvement in students' performance might not be solely due to professional development (Polly, 2015). 


\section{CONCLUSION}

This study is important as this is aimed at improving the algebraic content and pedagogical knowledge of sixth-grade algebra teachers. During the research, it became apparent that stakeholders believed one of the factors contributing to students' low performance in algebra could be due to lack of algebraic content and pedagogical knowledge of the in-service teachers. Results of this study suggested that the teachers who participated in this study lacked algebraic content and pedagogical knowledge. As the issue needed to be addressed immediately, it was found that the best way to address the issue was by conducting professional development. This MPD is essential in contributing towards the enhancement of algebraic content and pedagogical knowledge of sixth-grade mathematics teachers. Improvement in algebraic content and pedagogical knowledge will positively contribute towards the enhancement of students' algebra performance in these highly populated schools which could contribute to an improvement in students' algebra performance nationally.

The MPD was designed to address the needs of the sixth-grade mathematics teachers who took part in the study. The MPD was informed by best practices that have worked well for improving the content and pedagogical knowledge of teachers through professional development. The strengths of this MPD are three-fold. First, this MPD restructures the professional development to focus on subjects and also the areas in which teachers most need help. The participants of this study highlighted that they felt the previous professional development sessions they attended were unproductive as they were focused on generic issues such as classroom management or use of PowerPoint presentations in class. This problem has been addressed by focusing this mathematics professional development on the areas these participants identified as the areas in which they needed help. This is a major change from the professional development the participants have experienced before.

Second, this MPD is designed to provide opportunities for teachers to step out of their comfort zones and implement various instructional strategies through collaborations among mathematics teachers, peer observations, and common planning of lessons. I observed that participants followed the textbook word-for-word and they failed to identify mistakes in the textbook. This study's mathematics professional development is designed in a way that by the end of the session, the participants will have lesson plans for each of the algebra subtopics they will teach in sixth grade. Collaboratively planning the lesson and activities would help the participants to try new teaching strategies that they have devised. Moreover, they will be confident in trying new strategies instead of following the textbook word-for-word. Encouraging the participants to try new teaching strategies and providing them a platform on which to collaborate with other teachers is a key strength of this MPD.

Third, this MPD is designed to take into account the needs of the in-service teachers and the resources (or lack of resources) available to them. Participants of this study highlighted that they did not have access to resources or reference materials other than the prescribed textbooks. This MPD is designed to deliver mathematics professional development with minimal resources or no resources except the facilitators. Moreover, through this MPD the participants will learn how to use the tools available to them such as their smartphones to locate relevant resources. Participants will learn how to make use of what is available rather than focusing on what is not available to them. This is considered a strength because in the Maldives there is an unequal distribution of wealth and resources due to the geography. This 
MPD is designed in a way that could be delivered in any of the islands in the Maldives, which is also considered as a major strength of this MPD.

In a nutshell, the first implementation of this MPD improved participants' algebraic content and pedagogical knowledge as measured by DTAMS post-test results. This resulted in significantly improving student performance on algebra test scores. The results indicate that the participants have strengthened their instructional practices and contributed towards the improvement of algebra performance at the school level. These participants are now the nucleus of a group of experts and perhaps they could gradually improve algebra performance at the national level through collaborations with teachers across the country. It is noteworthy, that as this MPD was implemented with a small group of participants it cannot be generalized to a larger group. Therefore, it is recommended that this is tested and implemented in other schools and educational institutions before the results can be generalized.

\section{REFERENCES}

Ball, D. L., Thames, M. H., \& Phelps, G. (2008) Content knowledge for teaching: What makes it special? Journal of Teacher Education, 59(5), 389-407.

Barrett, N., Cowen, J., Toma, E., \& Troske, S. (2015). Working with what they have: Professional development as a reform strategy in rural schools. Journal of Research in Rural Education, 30(10), 1-18.

Baxter, J. A., Ruzicka, A., Beghetto, R. A., \& Livelybrooks, D. (2014). Professional development strategically connecting mathematics and science: The impact on teachers' confidence and practice. School Science and Mathematics, 114(3), 102113.

Borko, H. (2004). Professional development and teacher learning: Mapping the terrain. Educational Researcher, 33(8), 3-15.

Burrows, A. C. (2015). Partnerships: A systemic study of two professional developments with university faculty and k-12 teachers of science, technology, engineering, and mathematics. Problems of Education in the 21st Century, 65(1), 28-38.

Cohen, D. K., \& Hill, H. C. (2001). Learning policy. New Haven, CT: Yale University Press.

Desimone, L. M. (2009). Improving impact studies of teachers' professional development: Toward better conceptualizations and measures. Educational Researcher, 38(3), 181-199.

Ebert-May, D., Derting, T. L., Hodder J., Momsen, J. L., Long, T. M., \& Jardeleza, S. E. (2011). What we say is not what we do: Effective evaluation of faculty professional development programs. Bioscience, 61(7), 550-558.

Garet, M. S., Birman, B. F., Porter, A. C., Desimone, L., \& Herman, J. (1999). Designing effective professional development: Lessons from the Eisenhower program [and] technical appendices. Washington, DC: U. S. Department of Education.

Goldsmith, L. T., Doerr, H. M., \& Lewis, C. C. (2014). Mathematics teachers' learning: A conceptual framework and synthesis of research. Journal of Mathematics Teacher Education, 17(1), 5-36. 
Higgins, J., \& Parsons, R. (2009). A successful professional development model in mathematics: A system-wide New Zealand case. Journal of Teacher Education, 60(3), 231-242.

Hill, H. C., \& Ball, D. L. (2004). Learning mathematics for teaching: Results from California's mathematics professional development institutes. Journal for Research in Mathematics Education, 35(5), 330-351.

Jackson, L. D. (2009). Revisiting adult learning theory through the lens of an adult learner. Adult Learning, 20(3), 20-22.

Killion, J., \& Roy, P. (2009). Becoming a learning school. Oxford, OH: National Staff Development Council.

Knowles, M. S., Holton, E. F., III, \& Swanson, E. A. (2005). The adult learner: The definitive classic on adult education and human resource development (6th Ed.). Oxford, United Kingdom: Elsevier.

Knowlton, S., Fogleman, J., Reichsman, F., \& de Oliveira, G. (2015). Higher education faculty collaboration with $\mathrm{K}-12$ teachers as a professional development experience for faculty. Journal of College Science Teaching, 44(4), 46-53.

Krawec, J., \& Montague, M. (2014). The role of teacher training in cognitive strategy instruction to improve math problem solving. Learning Disabilities Research \& Practice, 29(3), 126-134.

Lane, K. L., Oakes, W. P., Powers, L., Diebold, T., Germer, K., Common, E. A., \& Brunsting, N. (2015). Improving teachers' knowledge of functional assessment-based interventions: Outcomes of a professional development series. Education and Treatment of Children, 38(1), 93-120.

Lehiste, P. (2015). The impact of a professional development program on in-service teachers' TPACK: A study from Estonia. Development, 66(18).

Lomos, C., Hofman, R. H., \& Bosker, R. J. (2011). Professional communities and student achievement-a meta-analysis. School effectiveness and school improvement, 22(2), 121-148.

Loucks-Horsley, S., Stiles, K. E., Mundry, S., Love, N., \& Hewson, P. W. (2010). Designing professional development for teachers of science and mathematics (3rd Ed.). Thousand Oaks, CA: Corwin.

Mansour, N., Albalawi, A., \& Macleod, F. (2014). Mathematics teachers' views on CPD provision and the impact on their professional practice. Eurasia Journal of Mathematics, Science \& Technology Education, 10(2), 101-114.

Mizell, H., Hord, S., Killion, J., \& Hirsh, S. (2011). New standards put the spotlight on professional learning. Journal of Staff Development, 32(4), 10-12.

Naseer, M. S. (2016). Algebraic content and pedagogical knowledge of sixth-grade mathematics teachers. Dissertation. Minneapolis, MN: Walden University.

Polly, D. (2015). Examining how professional development influences elementary school teachers' enacted instructional practices and students' evidence of mathematical understanding. Journal of Research in Childhood Education, 29(4), 565-582. 
Sowder, J. T. (2007). The mathematical education and development of teachers. In F.K. Lester, Jr., (Ed.), Second handbook of research on mathematics teaching and learning (pp. 157-223). Charlotte, NC: Information Age Publishing.

Strand, K., \& Mills, B. (2014). Mathematical Content Knowledge for Teaching Elementary Mathematics: A Focus on Algebra. The Mathematics Enthusiast, 11(2), 385-432.

Sykes, G. (1996). Reform of and as professional development. Phi Delta Kappan, 77(7), 464.

UNICEF \& NIE. (2014). Longitudinal study on the impact of curriculum reforms 20122013. Maldives: UNICEF Maldives Country Office.

Van Garderen, D. (2008). Middle school special education teachers' instructional practices for solving mathematical word problems: An exploratory study. Teacher Education and Special Education: The Journal of the Teacher Education Division of the Council for Exceptional Children, 31(2), 132-144. 